\title{
微分型構成方程式の比較検討
}

\author{
篠 原正之*1 ・梶原稔尚*2 - 船津 和 守*3
}

\section{Applicapability of Differential Constitutive Equations for Steady Shear Flow, Elastic Recovery and Uniaxial Elongational Flow of High Density Polyethylene}

\author{
ShINOHARA, Masayuki*1/KAJIWARA, Toshihisa*2/FunATSU, Kazumori*3
}

Experimental data were compared with the predictions of differential constitutive equations proposed by Larson, Giesekus and Phan-Thien and Tanner (PTT). Applicapability of these equations was investigated with steady shear flow, start up of uniaxial steady elongational flow and elastic recovery of shear and uniaxial elongation of three high density polyethylene having broad distribution of molecular weight. The following conclusions were obtained

(1) Larson, Giesekus and PTT-E model (Phan-Thien and Tanner model with non-linear term of exponential type) give good fit with the transient shear viscosities and transient uniaxial elongational viscosities for three HDPE.

(2) Larson model gives the best fit when non-linear parameter $\alpha$ equals to $0.5 \sim 0.9$ under steady shear and $0.1 \sim 0.2$ under transient uniaxial elongation. PTT-E gives the best results when $\alpha$ equals to 0.9 under steady shear and $0.1 \sim 0.2$ under steady uniaxial elongation. The best values of $\alpha$ in these two models are different for shear and elongational flow. The values of $\alpha$ are, however, similar in three HDPE samples which have different relaxation spectra.

(3) Of three models, the Giesekus model is the best from the point of applicapability to elastic recovery in shear and elongation of three constitutive models. PTT-E is moderate, and the Larson model shows unrealistic results.

Key words : Differential constitutive equation/Larson model/Giesekus model/PTT model/Elastic recoverable strain

*1 出光石油化学(侏) 樹脂研究所 市原市姉崎海岸 1-1（采 299-01）

Polymer Research Laboratory, Idemitsu Petrochemical Co., Ltd.,

Anesaki-Kaigan, Ichihara, Chiba 299-01 Japan

*2 九州工業大学 工学部 物質工学科

北九州市戸畑区仙水町 1-1 (

Department of Applied Chemistry, Kyushu Institute of Technology 1-1, Sensui-cho, Tobata-ku, Kitakyushu 804 Japan

*3 九州大学 大学院工学研究科 化学システム工学専攻 福岡市東区箱崎 6-10-1（广 812-81）

Department of Chemical Systems and Engineering, Kyushu University

6-10-1, Hakozaki, Higashi-ku, Fukuoka 812 Japan 1996.9.24 受理

\section{1. 緒言}

高分子製品の実用性能は原材料の因子以外に成形加 工条件に著しく依存する，このため射出, 紡系, シー ト，インフレーション，ブローなど各種成形法の解析 は, 原材料および成形条件の最適化のために必要不可 欠な技術である．各種成形法をモデリングする場合， 質量・運動量・エネルギーの各保存則を，材料固有の 力学的性質を表す構成方程式と熱的性質を組み合わせ て考察する必要がある．したがって，構成関係の決定 は重要な問題である.とくに材料の溶融状態における 力学的性質を表したレオロジー構成方程式の選定は, 成形法のモデリングの良否を決定するといっても過言 ではない. 
一般に, 粘弾性を有する高分子のレオロジー方程式 は複雑であり，かつては簡略化した定式化しかできず, 予測精度も不満足なものにならざるをえなかった。し かしながら近年コンピューターを利用した数值解法の 発達に伴って, 成形加工のモデリングとその数值シミ ュレーションが本格的となったことから, 構成方程式 に関しても従来の物性論的・基礎的な側面のみでなく, 工学的, 実用的な観点から検討される必要が生じてき た。

高分子溶融体の構成方程式は, 積分型および微分型 に分類される ${ }^{1) \sim 3)}$. 積分型の代表例は $\mathrm{K}-\mathrm{BKZ}$ 方程式 ${ }^{4)}$ であり, 数々の報告5),6) がある.一方, 微分型は, 他の 保存則が微分形式で書かれていることから, 高分子成 形加工 CAE の発展に伴って見直された感があり,こ こ $5 \sim 6$ 年で急速に進展した. Khan と Larson ${ }^{7)}$ は, 緩 和スペクトル以外に一つだけパラメータ（非線形パラ メータ）をもつ各種微分型構成方程式を, せん断およ び二軸の大変形応力緩和と流動開始時の一軸伸長粘度 で比較検討し, Larson モデル ${ }^{8)}$, Phan-Thien and Tanner モデル97 が比較的良く実験結果を表し, Giesekus モデル ${ }^{10)} も 二$ 軸伸長以外では適合性が良好であ ることを報告している。高橋 ${ }^{11)}$ は, Leonov, Larson, Giesekus の各モデルについて総説し, Leonov モデル のせん断流動への適用性について詳細な検討を行って (る ${ }^{12), 13)}$. 船津ら ${ }^{14), 15)}$ は, 各種微分型構成方程式の基 本流動に対する数值解の特徵を検討し，計算方法をま とめている．伊崎ら ${ }^{16)}$ は，特に一軸および二軸の伸長 粘度の時間依存性および定常值について詳細に検討し, 各モデルの特徴を明らかにしている，以上の研究によ り, 各モデルの詳細な特徴が明らかとなってきた.

本研究では, 3 種の分子量分布の広い高密度ポリエ チレンを用いて, Larson, Phan-Thien and Tanner, Giesekus の各モデルのせん断流動および一軸伸長流 動に対する適用性を検討した。 とくに, 実成形時の流 動がせん断流動と伸長流動を含む複雑な流れであるこ とを考慮して, せん断流動と伸長流動に対する非線形 パラメータの影響について検討した。さらに，非線形 パラメータの緩和スペクトル依存性について検討した。 そして各粘弾性モデルの予測性能を比較する観点から, 従来あまり検討されていない弾性回復ひずみについて も検討した。弾性回復ひずみは, 押出成形時のダイス ウェルや成形品の収縮に直接影響する重要な粘弾性量 である。

\section{2. 微分型構成方程式}

各方程式の定常せん断粘度, 第一法線応力差, 第二 法線応力差, 一軸および二軸の定常伸長粘度, 伸長粘
度の時間依存性の計算法については，すでにいくつか の報告例があるので，ここでは，弾性回復ひずみの計 算方法について説明する.

各構成方程式を以下に示す。

Larson モデル :

$$
\boldsymbol{\tau}+\lambda \frac{\delta \boldsymbol{\tau}}{\delta t}+\frac{2 \alpha \lambda}{3 G} \boldsymbol{D}: \boldsymbol{\tau}(\boldsymbol{\tau}+G \boldsymbol{1})=2 G \lambda \boldsymbol{D}
$$

Giesekus モデル :

$$
\boldsymbol{\tau}+\lambda \frac{\delta \boldsymbol{\tau}}{\delta t}+\frac{\alpha}{G} \boldsymbol{\tau}^{2}=2 G \lambda \boldsymbol{D}
$$

Phan-Thien and Tanner モデル :

$$
Y(\boldsymbol{\tau}) \boldsymbol{\tau}+\lambda\left\{\frac{\xi}{2} \hat{\tau}+\left(1-\frac{\xi}{2}\right) \check{\tau}\right\}=2 G \lambda \boldsymbol{D}
$$

(Phan-Thien and Tanner-1)

$$
Y(\boldsymbol{\tau})=1+\frac{\alpha}{G} \operatorname{tr}(\boldsymbol{\tau})
$$

(Phan-Thien and Tanner-E)

$$
Y(\boldsymbol{\tau})=\exp \left\{\frac{\alpha}{G} \operatorname{tr}(\boldsymbol{\tau})\right\}
$$

$\tau$ は余剩応力テンソル, $D$ は速度勾配テンソル, $G$ は 弾性率, $\lambda$ は緩和時間, 1 は単位テンソルである. $\alpha$ は 非線形パラメータであり, 各式ともに $0<\alpha<1$ となる

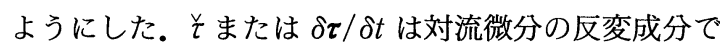
あり次式で書き表される.

$$
\frac{\delta \boldsymbol{\tau}}{\delta t}=\frac{\mathrm{d} \boldsymbol{\tau}}{\mathrm{d} t}-(\nabla v)^{+} \cdot \boldsymbol{\tau}-\boldsymbol{\tau} \cdot(\nabla v)
$$

また, $\hat{\tau}$ は対流微分の共変成分であり, 次式で表され る.

$$
\hat{\tau}=\frac{\mathrm{d} \tau}{\mathrm{d} t}+(\nabla v) \cdot \tau+\tau \cdot(\nabla v)^{+}
$$

以下，各モデルの頭文字をとって， L , G, PTT など と略記する. PTT の非線形項 $Y(\boldsymbol{\tau})$ には 2 種類が提案 されているので，(3) 式，（4）式をそれぞれPTT-

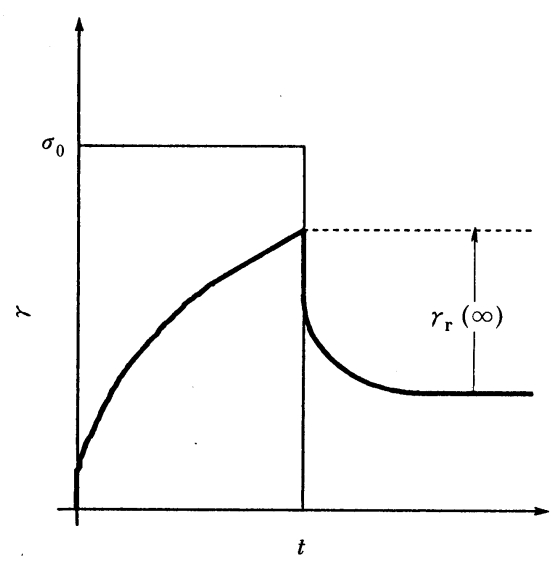

Fig.1 Schematic representation of elastic recovery following steady shear flow 
1 および PTT-E と名付けた。 L の $\tau: D$ は $\operatorname{tr}(\boldsymbol{\tau} \boldsymbol{D})$ とも書ける. PTT の $\xi$ は第二法線応力差と第一法線 応力差の比を表すパラメータである， $\xi$ があると Lodge-Meissner ${ }^{17)}$ の関係が成立しないことが報告さ れているため, 今回は $\xi=0$ とした。

$\mathrm{G}$ を用いた場合のせん断弾性回復性ひずみの計算方 法について以下に示す. 通常のように流線方向を 1 , 速 度勾配の方向を 2 としたとき, 各応力の時間微分は次 のように表される．緩和モード $i に$ 対して

$$
\begin{aligned}
& \frac{\mathrm{d} \tau_{11_{i}}}{\mathrm{~d} t}=-\frac{\tau_{11_{i}}}{\lambda_{i}}-\frac{\alpha}{G_{i} \lambda_{i}}\left(\tau_{11 i}^{2}+\tau_{12_{i}}^{2}\right)+2 \tau_{12_{i}} \frac{\mathrm{d} \gamma}{\mathrm{d} t} \\
& \frac{\mathrm{d} \tau_{22_{i}}}{\mathrm{~d} t}=-\frac{\tau_{22_{i}}}{\lambda_{i}}-\frac{\alpha}{G_{i} \lambda_{i}}\left(\tau_{22_{i}}^{2}+\tau_{12_{i}}^{2}\right) \\
& \frac{\mathrm{d} \tau_{12_{i}}}{\mathrm{~d} t}=-\frac{\tau_{12_{i}}}{\lambda_{i}}-\frac{\alpha}{G_{i} \lambda_{i}} \tau_{12_{i}}\left(\tau_{11_{i}}+\tau_{22_{i}}\right) \\
&+\left(G_{i}+\tau_{22_{i}}\right) \frac{\mathrm{d} \gamma}{\mathrm{d} t}
\end{aligned}
$$

（6）式から（8）式を次式の条件で解けば，せん断応 力解除後のひずみの挙動, すなわち弾性回復ひずみを 求めることができる.

$$
\sigma_{12}=\sum_{i} \tau_{12_{i}}=\left\{\begin{array}{l}
\sigma\left(t<0_{-}\right) \\
0\left(t>0_{+}\right)
\end{array}\right.
$$

$i$ は緩和モードであり， $\sigma$ は負荷したせん断応力であ る. 時刻 $t=0_{-}$で定常せん断応力 $\sigma_{12}$ を解除したとき, $t=0_{+}$におけるひずみ $\gamma_{\mathrm{r}}(0)$ は，変形前を $\gamma=0$ として (8) 式を緩和モードについて加えた次式より求められ る.

$$
\begin{aligned}
\frac{\mathrm{d} \sigma_{12}}{\mathrm{~d} t}= & -\sum_{i} \frac{\tau_{12_{i}}}{\lambda_{i}}\left\{1+\frac{\alpha}{G_{i}}\left(\tau_{11 i_{i}}+\tau_{22_{i}}\right)\right\} \\
& +\sum_{i}\left(G_{i}+\tau_{22_{i}}\right) \frac{\mathrm{d} \gamma}{\mathrm{d} t}
\end{aligned}
$$

すなわち（10）式の両辺に $\Delta t$ をかけ $\Delta t=0$ とおくこ とにより，瞬間回復性ひずみ $\gamma_{\mathrm{r}}(0)$ が得られる.

$$
-\sigma_{0}=\sum_{i}\left(G_{i}+\tau_{22_{i}}\right) \gamma_{\mathrm{r}}(0)
$$

$t=0_{-}$から $t=0_{+}$の間の各要素の応力の変化は次のよ うになる。

$$
\begin{gathered}
\Delta \tau_{12_{i}}=\left(G_{i}+\tau_{22_{i}}\right) \gamma_{\mathrm{r}}(0) \\
\Delta \tau_{11_{i}}=2 \tau_{12 i} \gamma_{\mathrm{r}}(0) \\
\Delta \tau_{22_{i}}=0
\end{gathered}
$$

$t=0_{+}$以後のひずみ $\gamma(t)$ は, $\Sigma \tau_{12 i}=0$.の条件のもとよ り，(10）式と（6）式，（7）式，（8）式を連立させ

Table 1 Characteristics of HDPE samples

\begin{tabular}{c|c|c|c|c}
\hline Sample & $\begin{array}{c}M_{\mathrm{n}} \\
\left(\times 10^{-4}\right)\end{array}$ & $\begin{array}{c}M_{\mathrm{w}} \\
\left(\times 10^{-4}\right)\end{array}$ & $M_{\mathrm{w}} / M_{\mathrm{n}}$ & $\begin{array}{c}M I \\
(\mathrm{~g} / 10 \mathrm{~min})\end{array}$ \\
\hline HDPE-1 & 1.41 & 19.7 & 14.0 & 0.25 \\
HDPE-2 & 0.86 & 26.0 & 30.2 & 0.05 \\
HDPE-3 & 2.13 & 29.4 & 13.8 & 0.02 \\
\hline
\end{tabular}

ることにより求められる. 緩和モードが $N$ 個の場合, $3 N+1$ の連立方程式を解けばよい. 長時間経過し平衡 に達した時の回復性ひずみを $\gamma_{\mathrm{r}}(\infty)$ で表した（Fig． 1). 以上がせん断弾性回復ひずみの計算方法である. このように，微分型は積分型に比較しひずみを容易に 求められる利点がある。一軸伸長の場合には, 伸長方 向を 1 として次式の条件のもとに解けば弾性回復ひず みを得ることができる。

$$
\sum_{i}\left(\tau_{11_{i}}-\tau_{22_{i}}\right)=0
$$

\section{3. 実験}

試料は 3 種の高密度ポリエチレンを用いた。メルト インデックスの高いほうから低いほうへ順に, HDPE1, HDPE-2, HDPE-3 とした. 試料の特性を Table 1 亿示した。動的粘弾性および低せん断速度領域の定 常せん断粘度, 第一法線応力差, 応力緩和の測定は, Rheometrics社製システム-4により行った. 直径 $1.25 \mathrm{~cm}$ のコーン\&プレートを用いた. 動的粘弾性の 周波数範囲は $0.01 \sim 600(\mathrm{rad} / \mathrm{s})$ とし, 定常流は $0.01 〜$ $1\left(\mathrm{~s}^{-1}\right)$ 程度とした。 ただし, HDPE-3 の低せん断速度 定常流動は, 試料が高粘度のためコーン\&プレートか

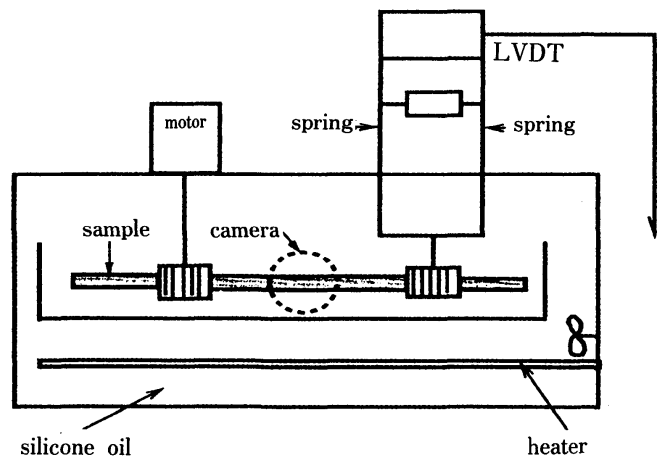

Fig. 2 Schematic diagram of uniaxial elongational rheometer

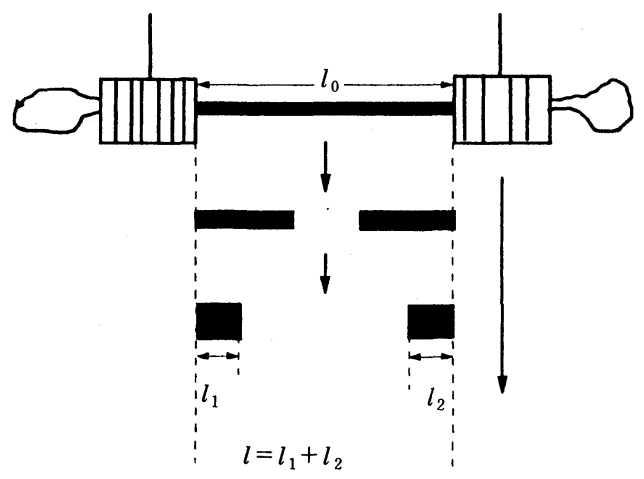

Fig.3 Measurement of elastic recovery with uniaxial elongational rheometer 
らはみ出し測定できなかった。高せん断速度領域の定 常せん断粘度の測定は, 島津製作所製のキャピラリー レオメーターを用いた。測定温度は HDPE-1, HDPE2 は $190^{\circ} \mathrm{C}, \mathrm{HDPE}-3$ は $220^{\circ} \mathrm{C}$ した。

せん断弾性回復ひずみの見積もりは古典的ではある が Tanner ${ }^{18)}$ の式

$$
\gamma_{r}(\infty)^{2}=2\left\{\left(\frac{d_{\mathrm{e}}}{d}\right)^{6}-1\right\}
$$

および Baglay ${ }^{19)}$ の式

$$
\gamma_{r}(\infty)=\left(\frac{d_{\mathrm{e}}}{d}\right)^{4}-\left(\frac{d_{e}}{d}\right)^{-2}
$$

を用いた。市販のクリープレオメーターも開発されて いるが，高分子の成形加工上重要な高せん断速度域の 測定は不可能であるため, これらの式で見積もった。 ここで, $d_{\mathrm{e}}$ はキャピラリー押出物の直径, $d$ はキャピ ラリーの直径であり,$d_{\mathrm{e}} / d$ はいわゆるスウェル比であ る. $\gamma_{\mathrm{r}}(\infty)$ はせん断回復性ひずみである. 測定には HDPE-1 を用いた。

非定常一軸伸長粘度の測定は岩本製作所(制製の延伸 レオメーターを用いた. 実験の詳細は別報 ${ }^{20)} に$ 詳し い. 測定温度は $150^{\circ} \mathrm{C}$ とた。一軸伸長後の弾性回復ひ

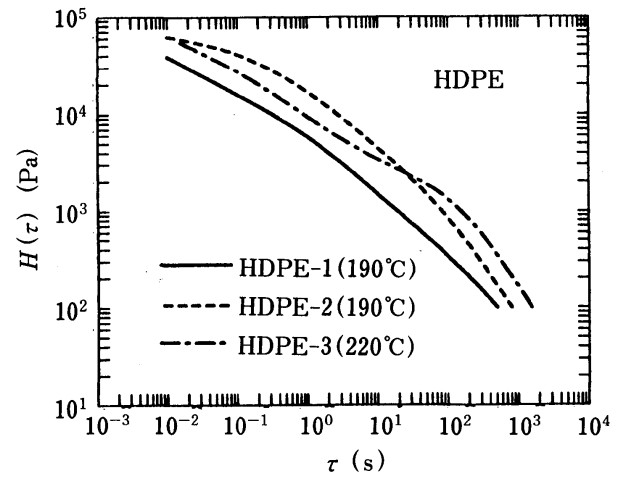

Fig.4 Relaxation spectrum of HDPE-1,2 and 3

Table 2 Relaxation spectra of HDPE samples

\begin{tabular}{c|c|c|c|c}
\hline \multirow{2}{*}{ Mode } & \multirow{2}{*}{$\tau_{i}(\mathrm{~s})$} & \multicolumn{3}{|c}{$H\left(\tau_{i}\right)(\mathrm{Pa})$} \\
\cline { 3 - 5 } & & $\begin{array}{c}\text { HDPE-1 } \\
\left(190^{\circ} \mathrm{C}\right)\end{array}$ & $\begin{array}{c}\text { HDPE-2 } \\
\left(190^{\circ} \mathrm{C}\right)\end{array}$ & $\begin{array}{c}\text { HDPE-3 } \\
\left(220^{\circ} \mathrm{C}\right)\end{array}$ \\
\hline 1 & $1.7 \times 10^{-3}$ & $9.5 \times 10^{4}$ & $1.3 \times 10^{5}$ & $1.4 \times 10^{5}$ \\
2 & $1 \times 10^{-2}$ & $3.9 \times 10^{4}$ & $6.2 \times 10^{4}$ & $5.4 \times 10^{4}$ \\
3 & $1 \times 10^{-4}$ & $1.6 \times 10^{4}$ & $4.1 \times 10^{4}$ & $2.3 \times 10^{4}$ \\
4 & $1 \times 10^{\circ}$ & $5.9 \times 10^{3}$ & $1.7 \times 10^{4}$ & $7.7 \times 10^{3}$ \\
5 & $1 \times 10^{1}$ & $1.5 \times 10^{3}$ & $4.5 \times 10^{3}$ & $2.9 \times 10^{3}$ \\
6 & $1 \times 10^{2}$ & $3.4 \times 10^{2}$ & $8.4 \times 10^{2}$ & $1.0 \times 10^{3}$ \\
7 & $5 \times 10^{2}$ & $1.0 \times 10^{2}$ & - & - \\
8 & $8 \times 10^{2}$ & - & $1.0 \times 10^{2}$ & - \\
9 & $1 \times 10^{3}$ & - & - & $2 \times 10^{2}$ \\
\hline
\end{tabular}

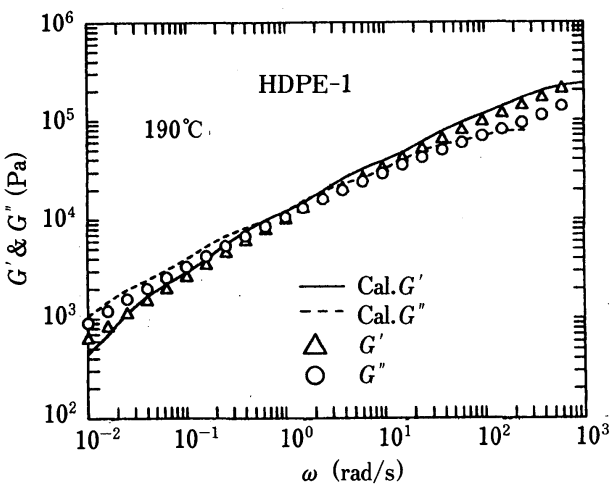

Fig.5 Storage modulus $G^{\prime}$ and loss modulus $G^{\prime \prime}$ of HDPE-1. The open circles and triangles show experimental data and solid lines represent calculated data from discrete relaxation spectrum

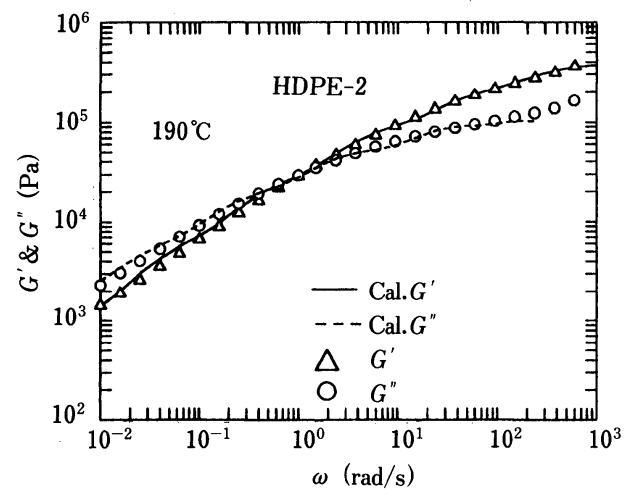

Fig.6 Storage modulus $G^{\prime}$ and loss modulus $G^{\prime \prime}$ of HDPE-2. The open circles and triangles show experimental data and solid lines represent calculated data from discrete relaxation spectrum

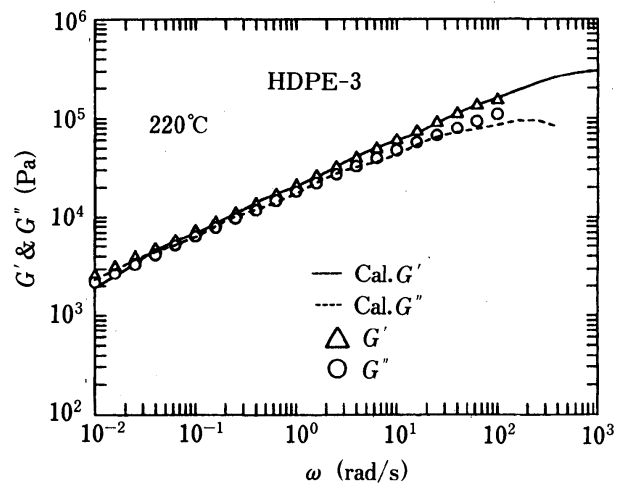

Fig.7 Storage modulus $G^{\prime}$ and loss modulus $G^{\prime \prime}$ of HDPE-3. The open circles and triangles show experimental data and solid lines represent calculated data from discrete relaxation spectrum 
ずみの測定も同装置で行った．装置を Fig. 2 に，測定 の概要を Fig. 3 に示した。試料を所定のひずみ速度で 一定ひずみまで伸長後ただちに試料中央部をはさみで 切断し，次式から回復性ひずみ $\varepsilon_{\mathrm{r}}$ を求めた。

$$
\varepsilon_{\mathrm{r}}=\ln \left(\frac{l_{0}}{l}\right)
$$

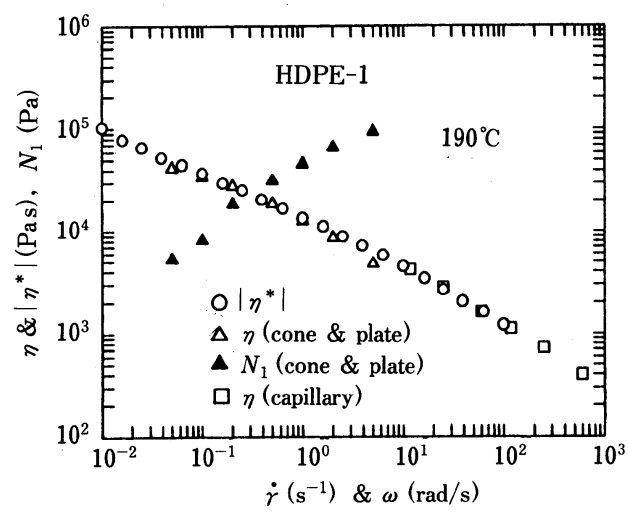

Fig. 8 Shear rate dependence of viscosity and normal stress difference of HDPE-1

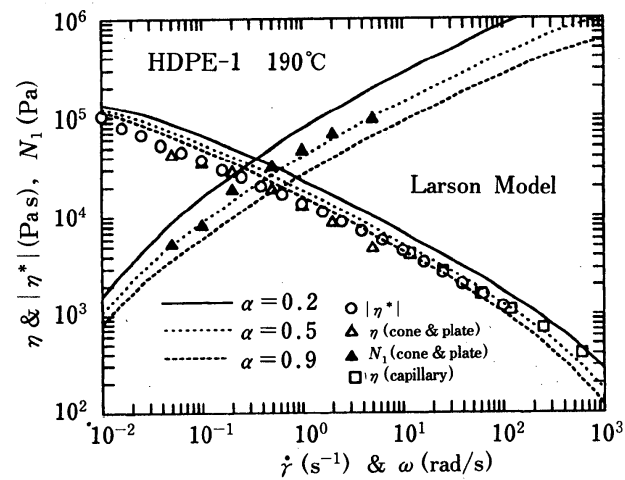

(a) Larson Model

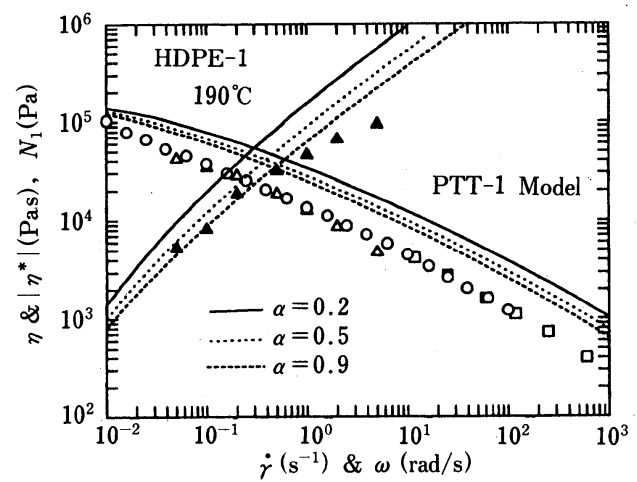

(c) PTT-1 Model $l_{0}$ は駆動ローラー間の距離, $l$ は収縮後の試料長さで ある。

\section{4. 結果および考察}

\section{1 緩和時間 $\lambda_{i}$ および緩和強度 $G_{i}$ の算出}

各試料の緩和スペクトル $H(\tau)$ を, 動的弾性率 $G^{\prime}$ お よび緩和弾性率 $G(t)$ から通常の一次式で算出した.

または

$$
H(\tau)=\left.\frac{\mathrm{d} G^{\prime}(\omega)}{\mathrm{d} \ln \omega}\right|_{\omega=1 / \tau}
$$

$$
H(\tau)=\left.\frac{\mathrm{d} G(t)}{\mathrm{d} \ln t}\right|_{t=\tau}
$$

$G_{i}$ および $\lambda_{i}$ は次式で求めた。

$$
\begin{gathered}
G_{i}=\frac{1}{2}\left\{H\left(\tau_{i}\right)+H\left(\tau_{i+1}\right)\right\} \ln \left(\frac{\tau_{i+1}}{\tau_{i}}\right) \\
\lambda_{i}=\sqrt{\tau_{i} \cdot \tau_{i+1}}
\end{gathered}
$$

動的粘弾性から得られた $G_{i}$ および $\lambda_{i}$ だけで動的粘弾 性を計算した場合，測定周波数の両端付近は当然合わ なくなる．そこで長時間側に $G_{i}$ および $\lambda_{i}$ を応力緩和 により一組追加した. 各試料の緩和スペクトルを Fig.

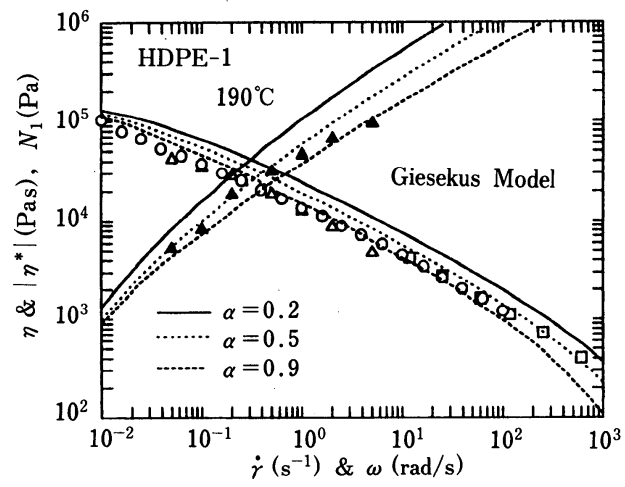

(b) Giesekus Model

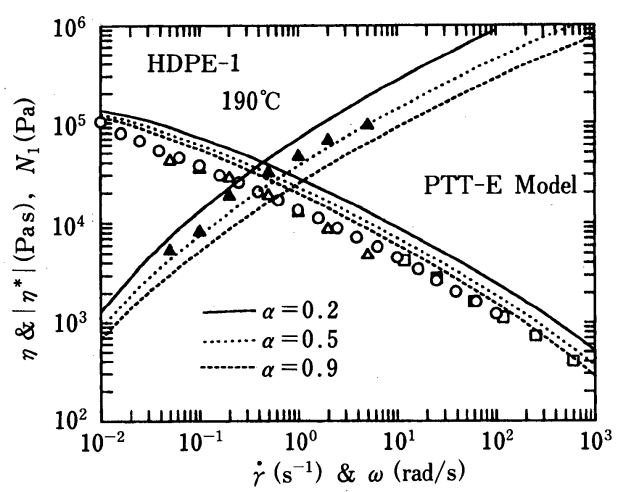

(d) PTT-E Model

Fig.9 Comparison of the predictions of viscoelastic constitutive equations with experimental data of HDPE-1 


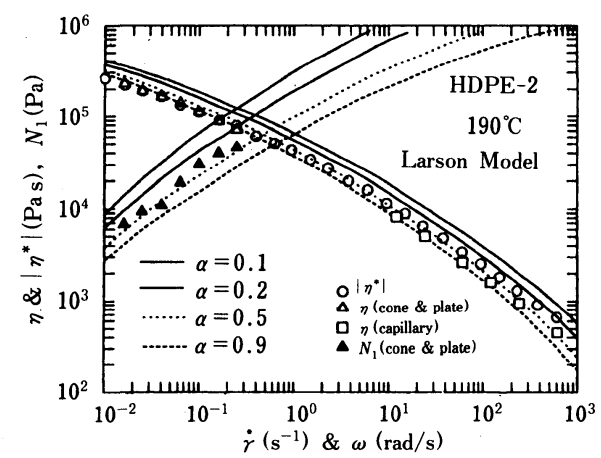

(a) Larson Model

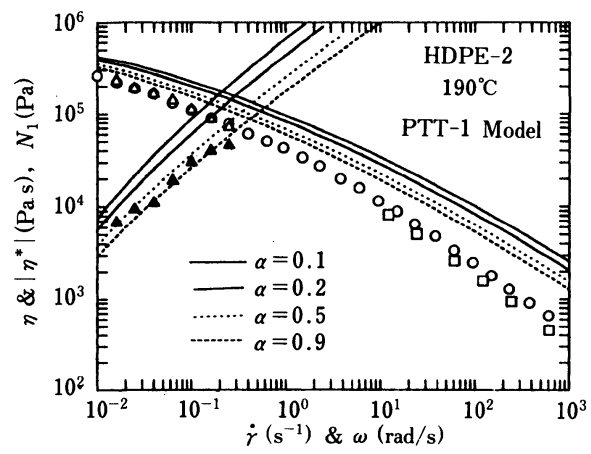

(c) PTT-1 Model

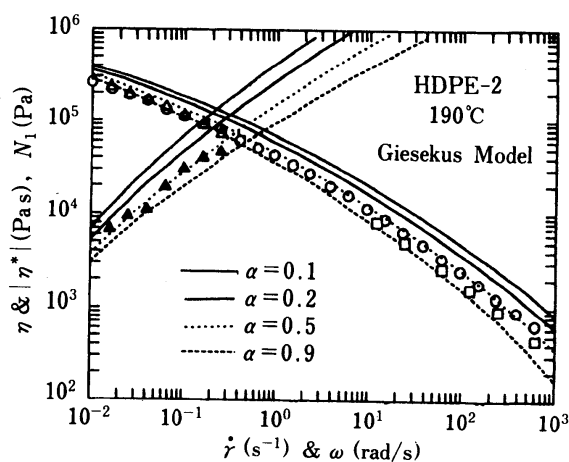

(b) Giesekus Model

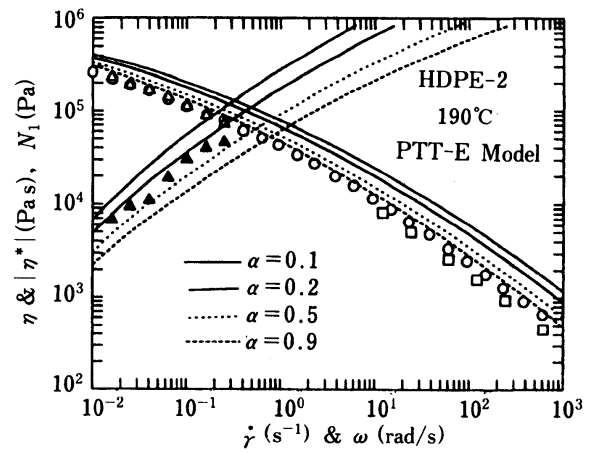

(d) PTT-E Model

Fig.10 Comparison of the predictions of viscoelastic constitutive equations with experimenatal data of HDPE-2

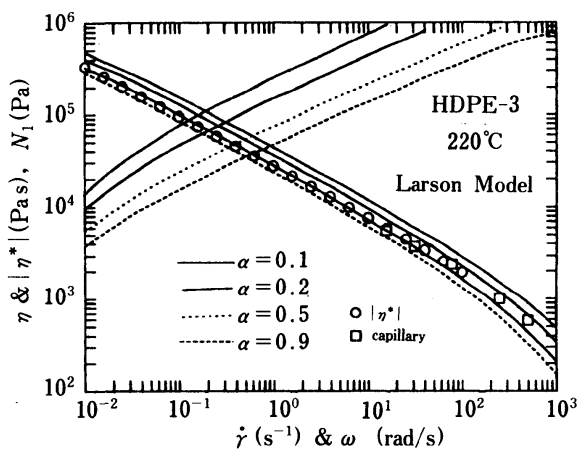

(a) Larson Model

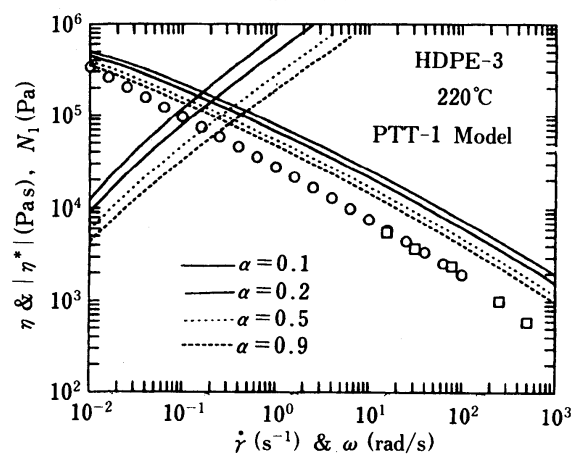

(c) PTT-1 Model

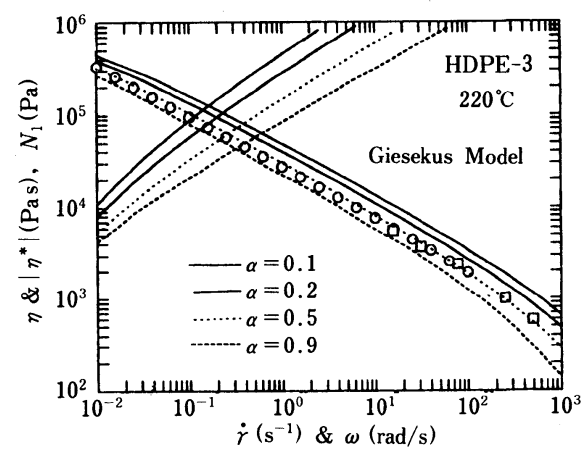

(b) Giesekus Model

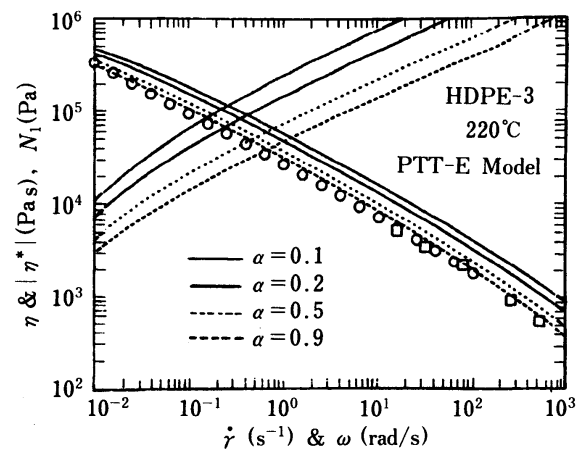

(d) PTT-E Model

Fig.11 Comparison of the predicitions of viscoelastic constitutive equations with experimental data of HDPE-3 
4 に示した. 図中, 100 秒以上のデー夕は緩和弾性率か ら得られたスペクトルである. 3 試料の $H\left(\tau_{i}\right), \tau_{i}$ の組 を Table 2 に, 動的粘弾性の測定值と $G_{i}, \lambda_{i}$ による計 算値の比較結果を Fig. 5〜 Fig.7 に示した. 数百 $\mathrm{rad} / \mathrm{s}$ 程度までは実測值と計算值はほぼ一致した。

\section{2 定 常 流}

Fig. 8 に HDPE-1 の定常せん断粘度・第一法線応 力差の測定結果を示した. 図中, ○は複素粘度の絶対 值， $・$ ・ はコーン\&プレートで測定した定常せん断 粘度・第一法線応力差， $\square$ はキャピラリーで測定した 定常せん断粘度を表す. Cox-Mertz 則が成立してい る. Fig.9(a)〜 (d) に HDPE-1 に対する L, G, PTT1, PTT-E の計算結果を測定結果とともに示した。ま た Fig.10 (a)〜 (d) に HDPE-2 を，Fig.11 (a) 〜 (d) に HDPE-3 の結果を示した. PTT-1 以外は非線形パ ラメータを $0.5 \sim 0.9$ 程度に設定することにより，せ

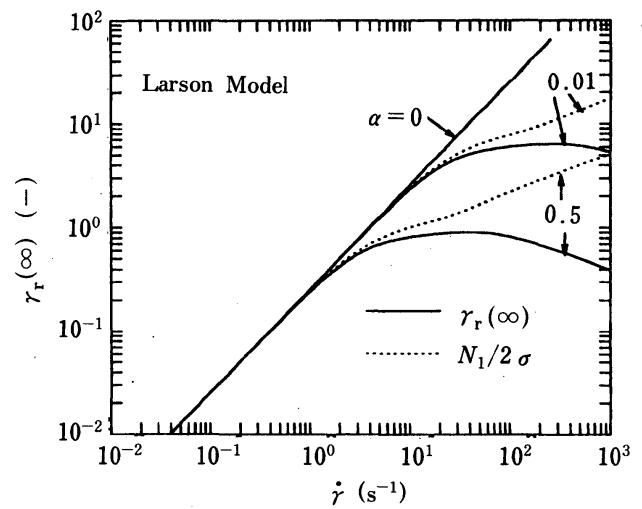

Fig.12 Predictions of elastic recovery by Larson model. Solid lines represent elastic recovery and dashed lines represent $N_{1} /$ $2 \sigma$ of steady state

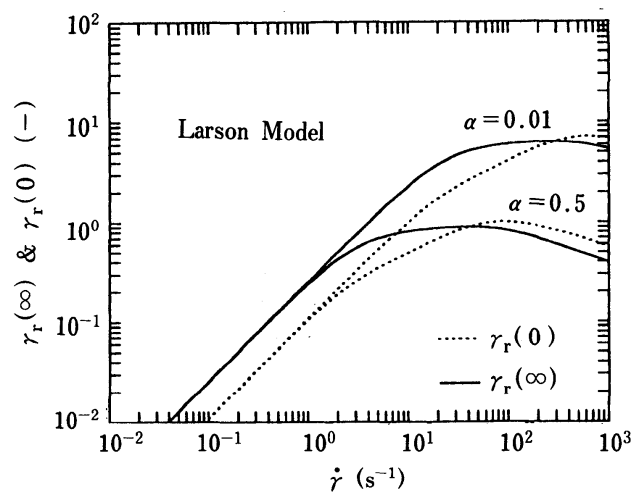

Fig.13 Predictions of elastic recovery by Larson model. Solid lines represent steady state elastic recovery and dashed lines represent instaneous elastic recovery
ん断粘度カーブを表現することが可能であった。 また せん断粘度でパラメータを設定した場合, HDPE-1・ HDPE-2 の法線応力は測定值よりも若干小さくなっ た. そして, HDPE-1〜3 の順に長時間側の緩和スペク トル分布は広くなるが非線形パラメータはほぼ一定で あり, 緩和時間分布で非線形度が大きく変化すること はなかった。

\section{3 各粘弾性モデルのせん断弾性回復ひずみ予 測性能}

まず検討した粘弾性モデルの特徴を検討するため, 3 個の緩和モードを (20) 式に入れ計算した。実際には HDPE-1 の 0.01〜1.0 (s) のモードを用いた. 弾性回 復ひずみの時間依存性を検討するためには, 当然のこ とながら 2 個以上の $G_{i}$ と $\lambda_{i}$ の組が必要である. Fig. 12 に の $\gamma_{\mathrm{r}}(\infty)$ の結果を示した。最長緩和時間の 10 倍まで時間積分した。計算は Runge-Kutta 法で行っ

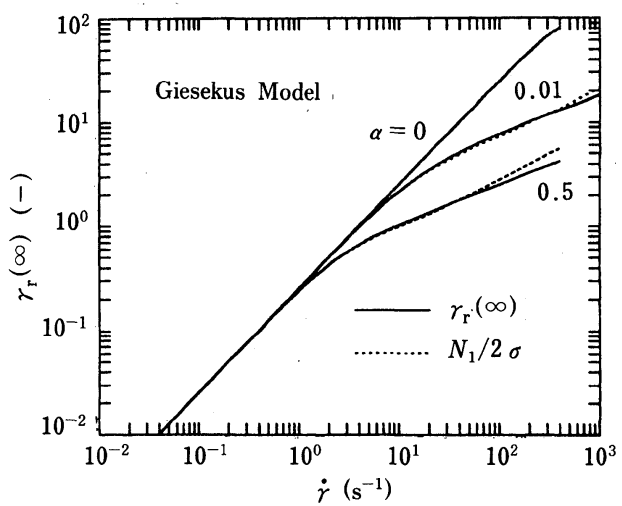

Fig.14 Predictions of elastic recovery of Giesekus model. Solid lines represent elastic recovery and dashed lines represent $N_{1} /$ $2 \sigma$ of steady state

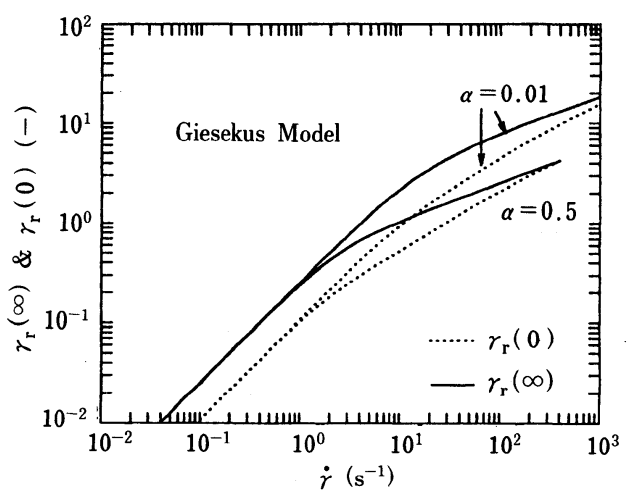

Fig.15 Predictions of elastic recovery by Giesekus model. Solid lines represent steady state elastic recovery and dashed lines represent instaneous elastic recovery 
た.線形領域では

$$
\gamma_{\mathrm{r}}(\infty)=\frac{N_{1}}{2 \sigma_{12}}
$$

であることが知られている。図中の $\alpha=0$ がこれに対 応している. $N_{1}$ は定常流動下の第一法線応力差, $\sigma_{12}$ は 定常せん断応力である.また非線形領域では

$$
\gamma_{\mathrm{r}}(\infty)>\frac{N_{1}}{2 \sigma_{12}}
$$

が成立することを，Vinogradov ら $^{21)}$ および最近では Laun $^{22)}$ が報告している. L の場合 $\gamma_{\mathrm{r}}(\infty)<N_{1} / 2 \sigma_{12}$ で あり, 報告されている実験結果とは逆の結果となった. また非線形領域で $\gamma_{\mathrm{r}}(\infty)$ はほとんど増加せず, 逆に高 せん断速度側で減少している点が特徴的である.Fig. 13 に の瞬間弾性回復ひずみと $\gamma_{\mathrm{r}}(\infty)$ を同時に示し た.このモデルの場合, 高せん断速度領域になると瞬

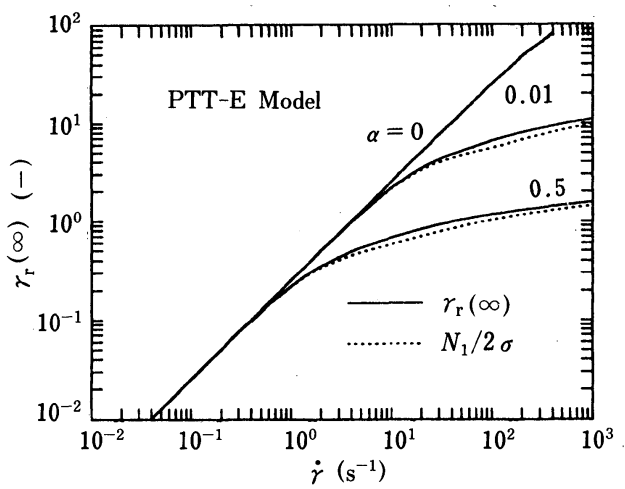

Fig .16 Predictions of elastic recovery of PTTE model. Solid lines represent elastic recovery and dashed lines represent $N_{1} / 2 \sigma$ of steady state

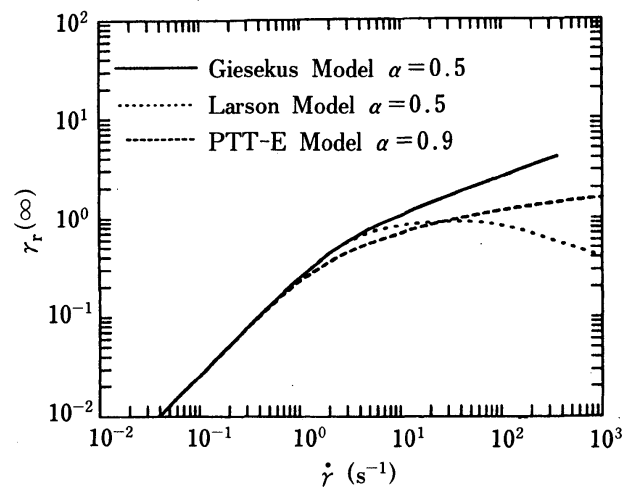

Fig.17 Comparison of the elastic recovery calculated by three models. The values of $\alpha$ are determined by fitting each model to the experimental data under steady shear flow
間弾性回復ひずみが $\gamma_{\mathrm{r}}(\infty)$ より大きくなってしまう。

Fig.14に同一の緩和モードを用いた場合の $\mathrm{G}$ の結 果を示した. $\gamma_{\mathrm{r}}(\infty)$ と $N_{1} / 2 \sigma$ はほほ等しく, せん断速 度の増加とともに $\gamma_{\mathrm{r}}(\infty)$ が増加する点が L と著しく 異なっている.Fig. 15 に G の瞬間弾性回復ひずみと $\gamma_{\mathrm{r}}(\infty)$ を同時に示した。非線形領域では, 時間に依存 した弾性回復ひずみがせん断速度とともに減少してい くが，Lのように逆転することはない.

Fig.16に PTT-Eの結果を示した. $\gamma_{\mathrm{r}}(\infty)$ の挙動は $\mathrm{G}$ と同様であるが, わずかに $\gamma_{\mathrm{r}}(\infty)>N_{1} / 2 \sigma て ゙ あ り$, 定性的にはこのモデルのみが報告された実験結果に一 致している.なお PTT-1 は PTT-E と全く同一の結 果であった。

Fig.17 に各モデルの $\gamma_{\mathrm{r}}(\infty)$ の比較結果を示した. $\mathrm{G}$ が最も大きな $\gamma_{\mathrm{r}}(\infty)$ を予測する.Fig. 18 に HDPE-1 の全緩和スペクトルを用いて各モデルの $\gamma_{\mathrm{r}}(\infty)$ を計 算した結果を示した. Fig.17 および Fig.18 の各モデ ルの非線形パラメータは, 定常せん断流動で決めた值

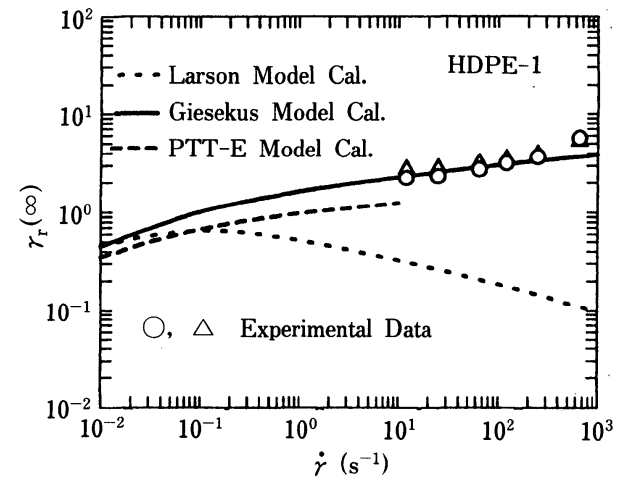

(a) comparison of calculated elastic recoveries with experimental data

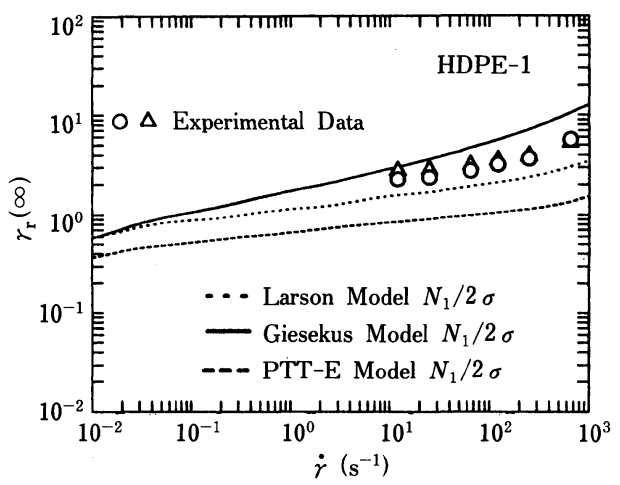

(b) comparison of $N_{1} / 2 \sigma$ with experimental data

Fig.18 Elastic recovery after shear HDPE-1 calculated by the three models with using all relaxation modes. The values of $\alpha$ are the same as in fig.17 
を用いた．図中にキャピラリースウェルから求めた $\gamma_{\mathrm{r}}$ $(\infty)$ も同時に示した。 ○は Tanner の式, $\triangle$ は Baglay の式である. Fig.19 はキャピラリースウェルの測定結 果である. Fig.18 に示したように，簡易法で得られた $\gamma_{\mathrm{r}}(\infty)$ に最も近いのは Gであった，PTT-E は L ほど 過少評価することはないが, 高せん断速度まで全スぺ クトルを入れて計算することは困難であった。ダイス ウェルの計算 ${ }^{23)}$ に対して G は有効と考えられる.また Larson は, L がせん断・一軸および二軸伸長の全ての 変形様式に対して実験との適合性がよいことを報告し ている。しかしながら今回の検討では弾性回復ひずみ が過少であり，改良の余地があるものと考えられた。

\section{4 一軸伸長粘度および非線形パラメータ}

Fig. 20 に HDPE-3 の一軸伸長粘度の測定結果を示 した.図から明らかなように高分子量タイプのHDPE-

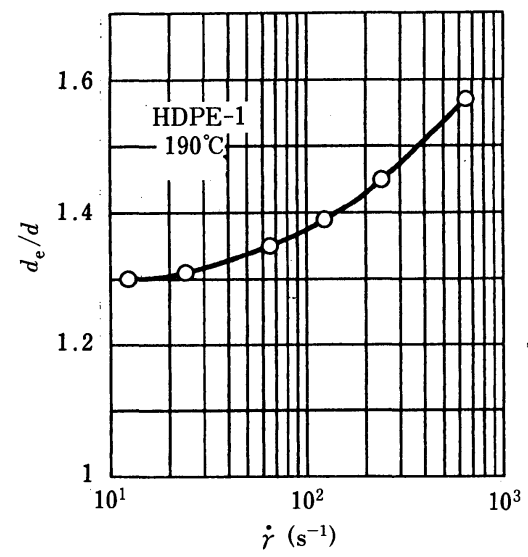

Fig.19 Shear dependence of die swell of HDPE-1

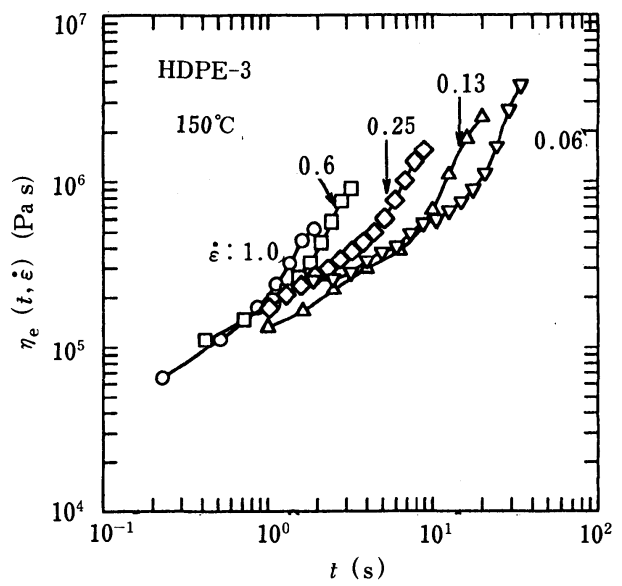

Fig.20 Transient elongational viscosities of HDPE-3
3 の場合, 測定範囲内では定常値が得られていない.こ こでは, 非定常一軸伸長粘度を計算結果と比較する。 Fig. 21 Fig.23 に, L, G, PTT-E の計算值と測定值 の比較を示した．流動の活性化エネルギーはせん断流 動下で得られた $6.3 \mathrm{kcal} /(\mathrm{mol} \cdot \mathrm{K})$ を用いた。せん断 流動と一軸伸長流動で流動の活性化エネルギーが同等 であることは以前 ${ }^{20)}$ の検討で明らかである. 図にはひ ずみ速度 $\dot{\varepsilon}$ が $0.6\left(\mathrm{~s}^{-1}\right)$ と $0.06\left(\mathrm{~s}^{-1}\right)$ の場合が示してあ る. 結果として, L は $\alpha=0.1 \sim 0.2 て ゙$ 実験值と合わせ ることができた。 $\mathrm{G}$ は測定範囲内ではフィィッナる $\alpha$ の值が決まらなかった.PTT-E は L と同様 $\alpha=0.1$ 〜 0.2 で実験值と合わせることができた。

非線形パラメー夕の值をせん断と一軸伸長で比較す

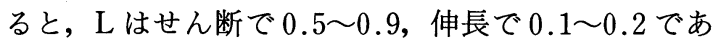
り，その差は比較的大きかった。 また PTT-Eではせ ん断で 0.9 , 伸長で $0.1 \sim 0.2$ であり, さらに差が大き かった. G は, せん断で $0.5 \sim 0.9$, 伸長では今回の測

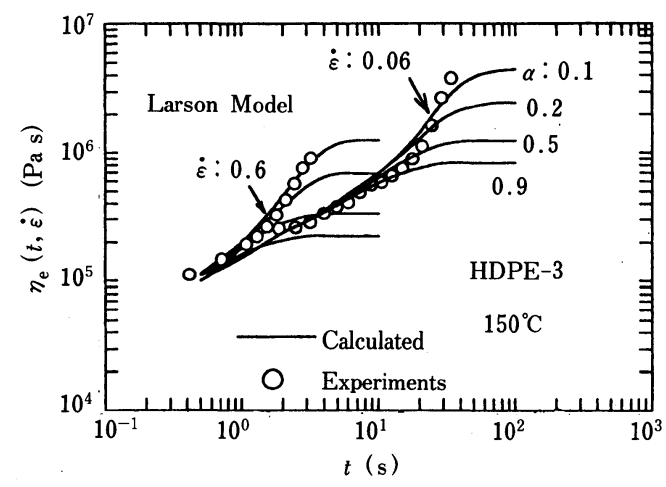

Fig. 21 Comparison of transient elongational viscosities of Larson model with experimental data of HDPE-3

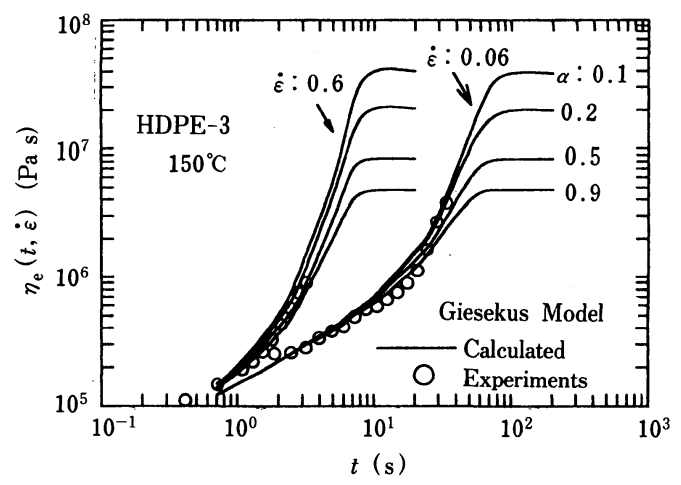

Fig.22 Comparison of transient elongational viscosities of Giesekus model with experimental data of HDPE-3 


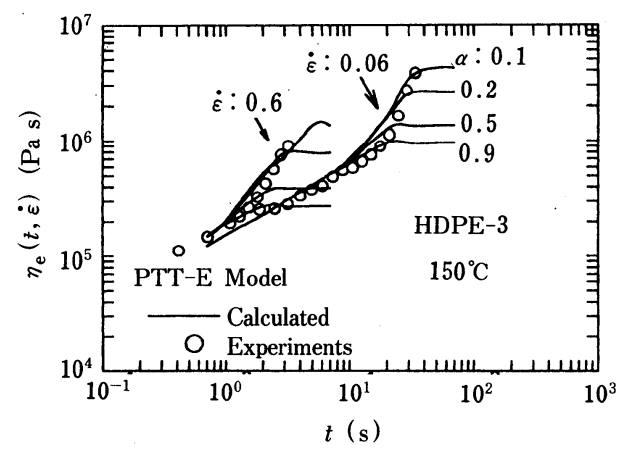

Fig.23 Comparison of transient elongational viscosities of PTT-E model with experimental data of HDPE-3

定範囲内ではパラメー夕值を決定できなかった。ただ し, 変形様式が一定ならば試料間でパラメー夕值に差 はなく，パラメー夕值の緩和スペクトル依存性は見い だせなかった。

\section{5 一軸伸長流動時の弾性回復ひずみ}

HDPE-3 を Hencky ひずみで 2.0 まで各ひずみ速 度で伸長した後, 200 秒経過時の弾性回復ひずみを測 定した結果を, 計算結果とともに Fig.24に示した. 非 線形パラメータは一軸伸長実験で決めた值を用いた。 ただし，Gのパラメー夕值は今回の測定範囲内では決 めることができなかったため, 比較的非線形性の大き い 0.9 を用いた. L はひずみ速度の高い領域で回復ひ ずみが 2.0 以上となり, 物理的に意味のない結果とな ってしまった. G, PTT-E は実験值よりも小さい值と なったが, G は非線形性の比較的大きいパラメー夕值 を用いたにもかかわらず実験值との差は小さかった。

\subsection{3 種の構成方程式の性能比較}

定常せん断粘度に関しては, PTT-1 以外は適用可 能であった。ただし弾性回復ひずみを含めて考えた場 合, Lの予測性能は低いものと推察された。また非定常 一軸伸長粘度に関しても, PTT-1 以外は適用可能で あった。ただし伸長時の弾性回復ひずみも含めて考え た場合，Lはひずみ速度の大きい領域で過大に弾性回 復ひずみを評価し，せん断の結果と同様弾性回復ひず みの観点から改良の余地があると考えられた。以上よ り, 粘度すなわち応力の予測には, PTT-1 以外のモデ ルが適用可能であるが，弾性回復ひずみなどクリープ を比較的正確に表現する必要のある場合には $\mathrm{G}$, 次い で PTT-Eが有効であると判断された。

\section{5. 結言}

分子量分布の広い高密度ポリエチレンを用いて, 代 表的な微分型粘弾性構成方程式である Larson モデル，

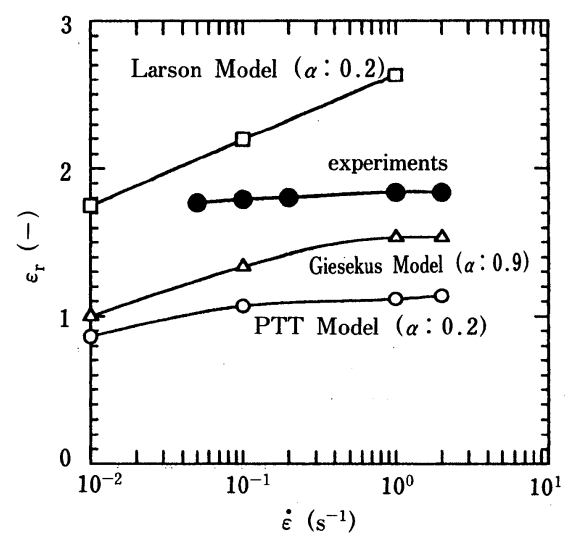

Fig.24 Comparison of the elastic recovery after elongation calculated by the three models

Giesekus モデル, Phan-Thien and Tanner (PTT) モデルの予測性能を比較し，以下の結果を得た。

（1）定常せん断粘度, 非定常一軸伸長粘度は Larson モデル, Giesekus モデル, 非線形項が指数型の PTT (PTT-E) モデルで実験結果を表現できた。

（2）Larson モデルおよび PTT-E モデルの非線 形パラメータはせん断で $0.5 \sim 0.9$, 伸長で $0.1 \sim 0.2$ であり，せん断と一軸伸長で大きく異なった。ただし， パラメータは緩和スペクトル分布に依存しなかった。

（3）せん断弾性回復ひずみの予測性能は, 実験值 に近い順に Giesekus モデル, PTT-E モデル, Larson モデルであった。

（4）一軸伸長時の弾性回復ひずみの予測性能は, 実験值に近い順に Giesekus モデル, PTT-E モデルで あった.Larson モデルは過大に弾性回復ひずみを予測 した.

（5）以上より，粘度すなわち応力の予測には Larson モデル, Giesekus モデル, PTT-E モデルが有効で あり, 弾性回復ひずみの予測には Giesekus モデル, 次 いで PTT-E モデルが有効であると判断された。

\section{参 考 文 献}

1）高橋雅興，小野木重治：日本レオロジー学会誌, 2, 95 (1974)

2）高橋雅興, 小野木重治：日本レオロジー学会誌, 3, 1 (1975)

3) 山本三三三 : 物体の変形学 (1972), 誠文堂新光社

4) Bernstein, B., Kearsley, E.A. and Zapas, L. J. : Trans. Soc. Rheol., 7, 391 (1963)

5）尾崎邦宏：日本レオロジー学会誌, 5, 163 （1977）

6) Wagner, M.H.:J. Non-Newtonian Fluid 
Mech., 4, 39 (1978)

7) Khan, S.A. and Larson, R.G. : J. Rheol., 31, 207 (1987)

8) Larson, R.G.: J. Non-Newtonian Fluid Mech., 13, 379 (1983)

9) Phan-Thien, N. and Tanner, R.I.: J. NonNewtonian Fluid Mech., 2, 353 (1977)

10) Giesekus, H. : J . Non-Newtonian Fluid Mech., 11, 69 (1982)

11）高橋雅興：日本レオロジー学会誌, 16, 53 (1988)

12）高橋雅興：日本レオロジー学会誌, 18, 18 (1990)

13) 高橋雅興：日本レオロジー学会誌, 18, 180(1990)

14）船津和守, 梶原稔尚：成形加工, 1, 170 (1989)

15）梶原稔尚, 鮫島昌彦, 船津和守: 第 4 回成形加工 学会講演要旨集, 89（1992）
16) Isaki, T., Takahashi, M., Takigawa, T. and Masuda, T. : Rheol. Acta, 30, 530 (1991)

17) Lodge, A.S. and Meissner, J.: Rheol. Acta, 11, 351 (1972)

18) Tanner, R.I.: J. Polym. Sci., A-2, 8, 2067 (1970)

19) Baglay, E.B.: Trans. Soc. Rheol., 5, 355 (1961)

20）篠原正之：日本レオロジー学会誌, 19, 118(1991)

21) Vinogradov, G.V., Malkin, A. Ya., Shumuskii, V.F. and Zabugina, M.P.: Vysokomol. Soyed., A11, 1221 (1969)

22) Laun, H.M.: J. Rheol., 30, 459 (1986)

23）桑野善文, 梶原稔尚, 船津和守：日本レオロジー 学会誌, 20, 184（1992） 